\title{
Analisis Kebiasaan Berolahraga di Masa Covid-19 Menggunakan Kerangka Kerja Gamifikasi Octalysis
}

\author{
Fitri Marisa ${ }^{1}$, Anastasia L Maukar ${ }^{2}$, Anik Vega Vitianingsih ${ }^{3}$, Erri Wahyu Puspitarini ${ }^{4}$, \\ Elta Sonalitha ${ }^{5}$, Rini Agustina ${ }^{6}$
}

${ }^{1}$ Universitas Widyagama Malang, Indonesia

${ }^{2}$ President University, Indonesia

${ }^{3}$ Universitas Dr Soetomo, Indonesia

${ }^{4}$ STMIK Yadika Bangil, Indonesia

${ }^{5}$ Universitas Merdeka Malang, Indonesia

${ }^{6}$ Universitas PGRI Kanjuruhan Malang, Indonesia

\section{Info Artikel}

Riwayat Artikel

Diterima: 05-07-2021

Direvisi: $10-07-2021$

Disetujui: 14-07-2021

Kata Kunci

Gamification; Octalysis;

Motivasi; Olah raga;

Corresponding Author

Anastasia L Maukar,

President University,

Tel. +62 815-5098-730

almaukar@gmail.com

\begin{abstract}
ABSTRAK
Saat ini seluruh penduduk dunia berjuang melawan wabah covid-19. Cara yang efektif melawan covid adalah melawannya dengan meningkatkan imut tubuh. Salah satu cara meningkatkan imun tubuh adalah menjaga hidup sehat dengan kebiasaan berolahraga. Namun faktanya sebagian besar orang cenderung enggan berolahraga dengan berbagai alasan. Maka penelitian ini menganalisis bagaimana motivasi masyarakat dalam berolahraga selama pandemic Covid-19 dengan analisis core drive Octalysis sehingga dapat digali lebih jauh doronga-dorongan apa saja yang mungkin lemah dan yang kuat sehingga bisa dijadikan referensi bagi pihak-pihak yang berkepentingan untuk menyelenggarakan kegiatan olahraga yang lebih diminati. Hasil analisis menunjukkan bahwa kecenderungan masyarakat berolahraga semasa pandemic Covid-19 adalah termotivasi ingin menjaga kesehatan diri sendiri dan menginspirasi orang lain untuk hidup sehat. Sedangkan suasana kompetisi maupun kerjasama dalam olah raga tidak terlalu dibutuhkan karena masyarakat tidak terlalu termotivasi dari dua hal tersebut.
\end{abstract}

\section{PENDAHULUAN}

Pesatnya perkembangan virus Covid-19 telah mengubah tatanan kehidupan. Semua negara berupaya untuk mengurangi dampak dari tersebarnya virus ini. Berdasarkan penelitian bahwa cara yang paling efektif dalam melawan Covid-19 adalah dengan meningkatkan imun tubuh. Salah satu cara meningkatkan imun tubuh adalah dengan berolahraga yang dilakukan secara konsisten [1],[2]. Namun pada kenyataannya sebagian besar masyarakat enggan berolahraga. Untuk itu perlu dilakukan kajian tentang bagaimana motivasi berolahraga setiap individu, apa yang membuat seseorang termotivasi atau sebaliknya [3],[4],[5]. Dari penggalian motivasi ini diharapkan dapat mengetahui penyebab dan solusi untuk meningkatkan motivasi berolahraga.

Salah satu pendekatan dalam menggali motivasi adalah model kerangka kerja gamifikasi Octalysis [6],[7]. Kerangka kerja ini memiliki 8 core drive sebagai patokan ukuran motivasi. Gamifikasi adalah sebuah pendekatan yang menggunakan komponen-komponen game dalam menyelesaikan permasalahan non-game [7]. Tujuan dari gamifikasi adalah meningkatkan retensi ataupun motivasi pengguna dalam menggunakan sistem gamified [8], [9]. Sementara Octalysis adalah salah satu kerangka kerja dalam gamifikasi yang fokus pada 
penggalian core drive. Prinsip Octalysis adalah mempercayai bahwa setiap tindakan seseorang melakukan sesuatu didasari oleh dorongan dari dalam diri sendiri (core drives) yang berjumlah 8 jenis [6],[10],[11]. Ketika seseorang enggan melakukan sesuatu atau termotivasi melakukan sesuatu dapat dilihat dari nilai core drive mereka.

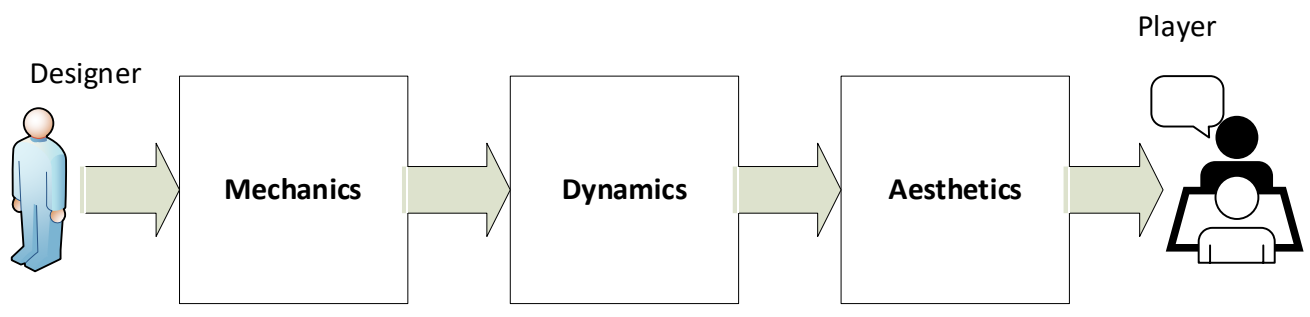

Gambar 1. Gamification Concept [12]

Untuk itu penelitian ini bertujuan untuk menganalisis dorongan-dorongan apa saja yang mempengaruhi seseorang berolah raga sehingga analisis ini dapat digunakan pihak yang berkepentingan seperti pengembang aplikasi olah raga, pengelola klub olah raga, perusahaanperusahaan yang ingin mendesain program olahraga pada karyawannya atau bidang-bidang lain dapat menggunakan analisis ini sebagai referensi mereka menyusun program.

\section{METODE}

Penelitian ini didesain dengan pendekatan uji perbandingan analisis kuesioner dengan skala likert digunakan untuk menjaring data kuesioner dari pertanyaan-pertanyaan kepada responden dengan skala yang terukur [8] dan skala octalysis digunakan untuk mengukur dan menganilis core drive responden dalam kebiasaan mereka berolahraga [9]. Perbandingan dilakukan untuk menguatkan analisis, selanjutnya hasil akan dibandingkan dan dianalisis. Gambar 2 menggambarkan metode penelitian yang dilakukan dalam penelitian ini.

Berikut adalah langkah-langkah metodologi penelitian dalam penelitian ini:

1. Mendesain dan mendistribusikan kuesioner kepada masyarakat umum, sampel dipilih secara acak masyarakat umum yang melakukan olah raga baik yang rutin ataupun yang tidak. Jumlah sample 58 responden. Pertanyaan menggunakan skala likert 4 jawaban yang isinya menggali data 8 core drive dalam motivasi berolahraga.

2. Melakukan tabulasi data kuesioner setelah data diisi semua responden.

3. Melakukan uji analisis skala liket dengan aturan pengujian core drive octalysis dengan skala likert [8], [9].

4. Melakukan uji analisis skala octalysis dengan aturan pengujian skala kerangka kerja octalysis [6] .

5. Melakukan analisis perbandingan terhadap 2 metode dilanjutkan dengan rekomendasi terhadap hasil skor masing-masing core drive. 


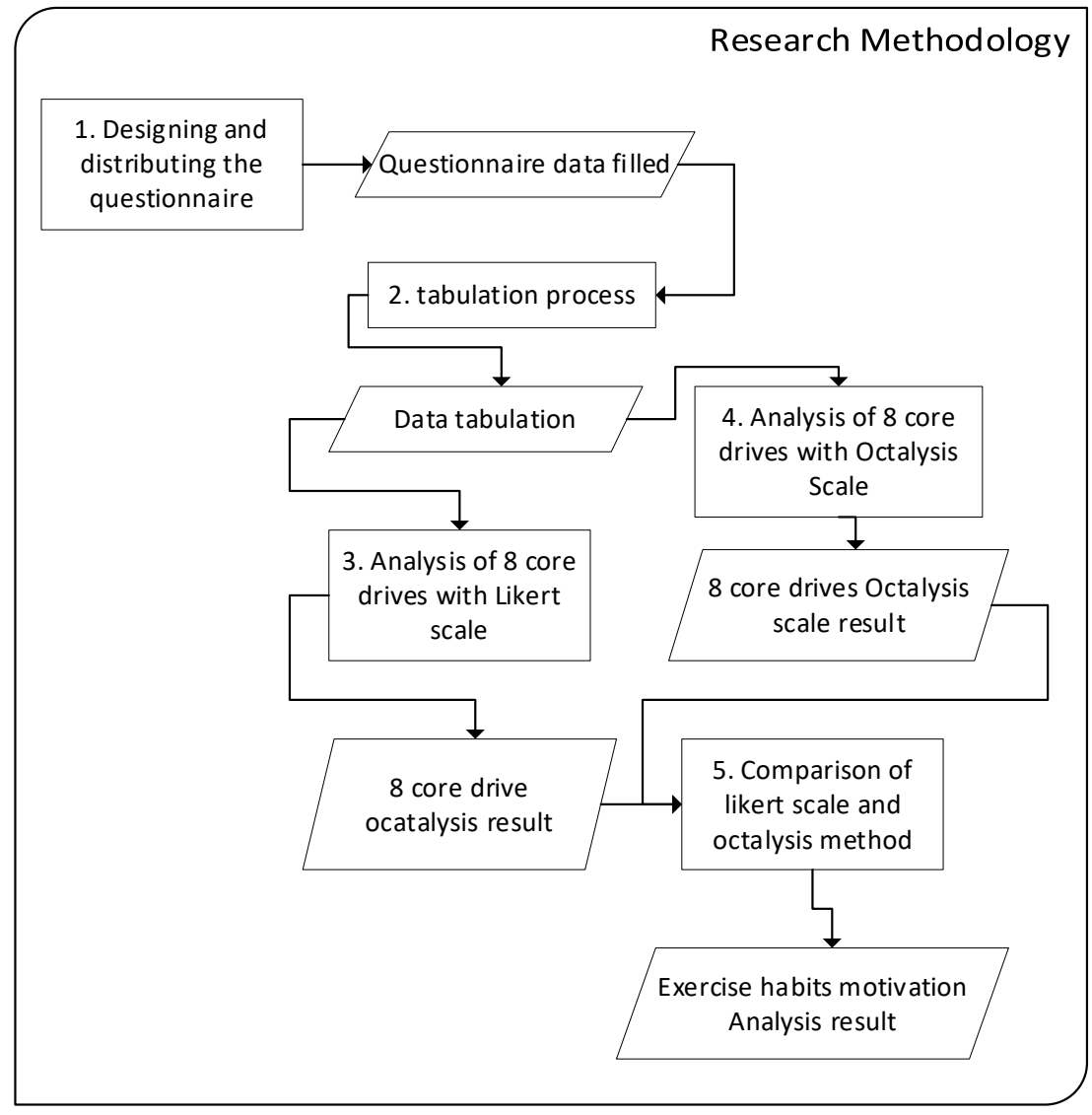

Gambar 2. Research Methodology

\section{HASIL DAN PEMBAHASAN}

Pengujian data pertama dilakukan dengan analisis skala likert. Data skor dikelompokkan berdasarkan kelompok core drive dan ditotal. Selanjutnya dibuat skala rentangan untuk kategori masing-masing total skor core drive, dibuat dalam 4 kategori: "Sangat Rendah (58 - 101)", "Rendah (102 - 145)", "Tinggi (146-189)" dan "Sangat Tinggi $(190$ - 233)". Dari hasil pengujian data didapat data total skor dan kategori dari 8 core drive semuanya berada pada kategori "Tinggi" (Tabel 1).

Tabel 1. Octalysis Likert Scale Analysis Result

\begin{tabular}{lll}
\hline Core Drives & Total Score & Category \\
\hline C.D.1 Epic Meaning and Calling & 178 & Tinggi \\
C.D.2 Development adan & 170 & Tinggi \\
$\quad$ Accomplishment & 166 & Tinggi \\
C.D.3 Empowering of Creativity and & 183 & Tinggi \\
$\quad$ Feedback & 172 & Tinggi \\
C.D.4 Ownership and Possession & 157 & Tinggi \\
C.D.5 Social Influence and $\quad$ Relatedness & 148 & Tinggi \\
C.D.6 Scarcity and Impatience & Tinggi \\
C.D.7 Unpredictability and Curiosity & 153 & \\
C.D.8 Loss and Avoidance Refers & 153 & \\
\hline
\end{tabular}

Pengujian data kedua dilakukan dengan analisis skala octalysis. Data dikelompokkan berdasarkan kelompok core drive dan ditotal. Selanjutnya dibuat skala rentangan sebanyak 10 rentangan. Penentuan 10 rentangan didasarkan pada skor maksimal skala Octalysis [6]. Dari 
hasil pengujian skala octalysis didapat data total skor dan kelompok rentangan dari 8 core drive yang beragam (Tabel 2).

Tabel 2. Octalysis Likert Scale Analysis Result

\begin{tabular}{|c|c|c|c|}
\hline Core Drives & Total Score & Scale & Target \\
\hline $\begin{array}{l}\text { C.D. } 1 \text { Epic Meaning and } \\
\text { Calling }\end{array}$ & 178 & 8 & 10 \\
\hline C.D.2 Development adan & & & \\
\hline Accomplishment & 170 & 7 & 10 \\
\hline $\begin{array}{l}\text { C.D.3 Empowering of } \\
\text { Creativity and } \\
\text { Feedback }\end{array}$ & 166 & 7 & 10 \\
\hline $\begin{array}{c}\text { C.D.4 Ownership and } \\
\text { Possession }\end{array}$ & 183 & 8 & 10 \\
\hline $\begin{array}{c}\text { C.D.5 Social Influence } \\
\text { and Relatedness }\end{array}$ & 172 & 7 & 10 \\
\hline $\begin{array}{c}\text { C.D.6 Scarcity and } \\
\text { Impatience }\end{array}$ & 157 & 7 & 10 \\
\hline $\begin{array}{l}\text { C.D.7 Unpredictability } \\
\text { and Curiosity }\end{array}$ & 148 & 6 & 10 \\
\hline $\begin{array}{l}\text { C.D.8 Loss and } \\
\text { Avoidance Refers }\end{array}$ & 153 & 6 & 10 \\
\hline
\end{tabular}

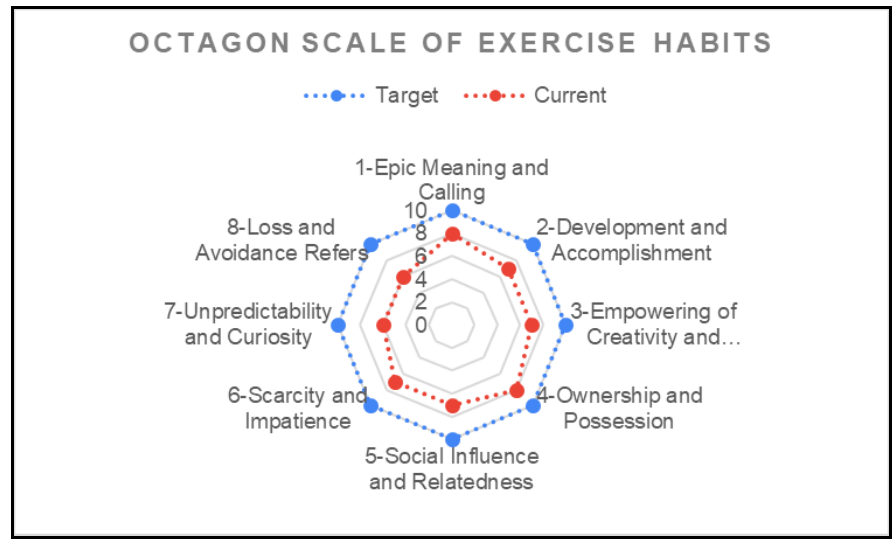

Gambar 3. Octagon Scale of Exercise habit

Jika dibandingkan hasil yang didapat dari analisis skala likert dengan skala Octalysis terdapat perbedaan pada keberagaman hasil yang diperoleh skala Octalysis. Skala likert hanya menunjukkan satu hasil homogen sehingga diasumsikan bahwa tingkat motivasi core drive masyarakat terhadap exercise habits cenderung sama, sehingga kurang dapat didapat pengetahuan yang lain terkait bagaimana kondisi core drive masing-masing. Sedangkan hasil analisis skala Octalysis dapat menyajikan skala yang beragam (Tabel 2) dan dilengkapi dengan skala Octagon (Gambar 3) yang dapat menggambarkan posisi keadaan masing-masing core drive responden jika dibandingkan dengan target core drive ideal [8], [9], [11].

Berdasarkan uji analisis octalysis didapatkan kelompok nilai tertinggi dengan skala 8 yaitu CD-1 Epic Meaning and Calling dan CD-4 Ownership and Possession. Dari dua skala ini dapat disimpulkan bahwa kecenderungan responden termotivasi berolah raga di masa Covid-19 karena ingin menginspirasi orang lain untuk melakukan olah raga serta lebih termotivasi untuk berolahraga jika terfasilitasi dengan hal-hal yang dapat mengeksplorasi kemajuan mereka. Kelompok berikutnya adalah kelompok skala 7 yaitu : CD-2 Development yang berhubungan dengan motivasi pencapaian prestasi, CD-3 Empowering of Creativity and 
Feedback berhubungan dengan motivasi berkreasi jenis-jenis olahraga, CD-5 Social Influence and Relatedness yang berhubungan dengan motivasi bekerja sama ataupun berkompetisi dalam olah raga, dan CD-6 Scarcity and Impatience yang berhubungan dengan motivasi melakukan olah raga yang langka yang jarang dilakukan orang lain. Kelompok ini nilainya lebih rendah artinya respondent tidak terlalu termotivasi dalam berprestasi, berkreasi, dan berkompetisi dalam menjalankan olah raga di masa pandemic Covid-19. Sedangkan nilai terendah yaitu skala 6 ada pada kelompok: CD-7 Unpredictability and Curiosity dan CD-8 Loss and Avoidance Refers. CD-7 dan CD-8 adalah lanjutan dari penggalian motivasi berkompetisi maka dapat disimpulkan bahwa semakin digali motivasi berkompetisi dari menjalankan olah raga semasa pandemic Covid-19 adalah kecil.

\section{SIMPULAN DAN SARAN}

Dari penelitian ini dapat disimpulkan bahwa skala Octalysis dapat mendeteksi dan menganalisis motivasi seseorang melakukan kegiatan tertentu secara lebih detil. Dan dari hasil eksperimen menyimpulkan bahwa kecenderungan masyarakat berolahraga semasa pandemic Covid-19 adalah termotivasi ingin menjaga kesehatan diri sendiri dan menginspirasi orang lain untuk hidup sehat. Sedangkan suasana kompetisi maupun kerjasama dalam olah raga tidak terlalu dibutuhkan karena masyarakat tidak terlalu termotivasi dari dua hal tersebut. Oleh karena ini, dari penelitian ini dapat dijadikan referensi bagi pihak yang berkepentingan membutuhkan data yang berkenaan dengan motivasi berolahraga semasa pandemic.

\section{DAFTAR PUSTAKA}

[1] J. Siahaan et al., Dinamika Merdeka Belajar dan Merdeka Olahraga pada Masa Pandemi Covid-19. 2020.

[2] S. L. Reiner, G. H. Smith, and R. B. Davis, "Exercise participation and subjective wellbeing of collegiate athletes during COVID-19 Pandemic," J. Hum. Sport Exerc., vol. 17, no. 3, pp. 1-12, 2021, doi: 10.14198/jhse.2022.173.16.

[3] Sepriadi, "PENGARUH MOTIVASI BEROLAHRAGA DAN STATUS GIZI TERHADAP TINGKAT KEBUGARAN JASMANI Sepriadi," J. PENJAKORA, vol. 4, no. $1,2017$.

[4] Z. Đogaš et al., "The effect of COVID-19 lockdown on lifestyle and mood in Croatian general population: A cross-sectional study," Croat. Med. J., vol. 61, no. 4, pp. 309318, 2020, doi: $10.3325 / \mathrm{cmj} .2020 .61 .309$.

[5] M. López-Moreno, M. T. I. López, M. Miguel, and M. Garcés-Rimón, "Physical and psychological effects related to food habits and lifestyle changes derived from covid-19 home confinement in the spanish population," Nutrients, vol. 12, no. 11, pp. 1-17, 2020, doi: 10.3390/nu12113445.

[6] Y.-K. Chou, Actionable gamification: Beyond points, badges, and leaderboards. 2016.

[7] J. Landsell and E. Hägglund, Towards a Gamification Framework: Limitations and opportunities when gamifying business processes. 2016.

[8] F. Marisa, S. Sakinah, S. Ahmad, and Z. I. Mohd, "Analysis Of Relationship CLV with 8 Core Drives Using Clustering K-Means and Octalysis Gamification Framework," $J$. Theor. Appl. Inf. Technol., vol. 98, no. 20, pp. 3151-3164, 2020, [Online]. Available: http://www.jatit.org/volumes/Vol98No20/6Vo198No20.pdf.

[9] F. Marisa, S. S. Syed Ahmad, Z. I. Mohd Yusoh, A. L. Maukar, R. D. Marcus, and A. A. Widodo, "Evaluation of Student Core Drives on e-Learning during the Covid-19 with Octalysis Gamification Framework," Int. J. Adv. Comput. Sci. Appl., vol. 11, no. 11, pp. 104-116, 2020, doi: 10.14569/IJACSA.2020.0111114.

[10] R. M. Toasa, E. Celi, L. Herrera, and U. T. Israel, "Using accomplishment from Octalysis Framework in a Dynamic Game," in 2020 15th Iberian Conference on 
Information Systems and Technologies (CISTI), 2020, no. June, pp. 24-27.

[11] F. Marisa, T. M. Akhriza, A. L. Maukar, and A. R. Wardhani, "Gamifikasi (Gamification) Konsep dan Penerapan," JOINTECS (Journal Inf. Technol. Comput. Sci., vol. 3, no. 28, pp. 219-228, 2020.

[12] K. Robson, K. Plangger, J. H. Kietzmann, I. McCarthy, and L. Pitt, "Is it all a game? Understanding the principles of gamification," Bus. Horiz., vol. 58, no. 4, pp. 411-420, 2015, doi: 10.1016/j.bushor.2015.03.006. 